\title{
Effect of lead in vitro on water metabolism and osmotic fragility of human erythrocytes
}

\author{
I KARAI, ${ }^{1} \mathrm{~K}$ FUKUMOTO, ${ }^{2} \mathrm{~K}$ KAGEYAMA,${ }^{3}$ AND S HORIGUCHI ${ }^{1}$ \\ From the Department of Preventive Medicine and Public Health, 'Osaka City University Medical School, \\ Abeno-ku, Osaka Prefectural Institute of Occupational Health, ${ }^{2}$ Higashi-ku, and Department of Physiology, ${ }^{3}$ \\ Osaka City University Medical School, Abeno-ku, Osaka, 545 Japan
}

\begin{abstract}
The addition of lead to normal human blood was previously found to cause a decrease in erythrocyte osmotic fragility in vitro. The mechanism of the decreased osmotic fragility caused by lead has not been completely clarified, but the following hypothesis has been proposed. Lead causes a leakage of water from erythrocytes, thus more water can enter the cell before haemolysis occurs. There has been no report, however, of the direct measurement of the intracellular water content of erythrocytes treated with lead. This study has tried to clarify the relation between intracellular water and the osmotic fragility of lead-treated erythrocytes in vitro. The results showed that $0.05 \mu \mathrm{M} / \mathrm{ml}$ of lead decreased the osmotic fragility, the intracellular water content, and intracellular potassium and mean corpuscular volume, increased the plasma water content and trapped water content, and contracted the erythrocyte shape. These changes corresponded well with each other, and close coincidence of the osmotic fragility and the intracellular water content was also observed.
\end{abstract}

In previous papers ${ }^{12}$ we observed a decreased erythrocyte osmotic fragility in workers occupationally exposed to lead compared with controls and found a dose-response relationship between the blood lead concentrations and the osmotic fragility in lead workers using the coil planet centrifuge (CPC) method. ${ }^{3}$ We also observed, by an in vitro experiment, ${ }^{4}$ that the addition of lead to normal human blood caused a decrease in the osmotic fragility using the CPC method.

The exact mechanism of the decreased osmotic fragility is not completely understood, but the following hypothesis has been generally accepted. The addition of lead to blood causes a leakage of potassium accompanying water from the erythrocytes, which means that more water can enter the cell before haemolysis occurs. ${ }^{5}$ There has been no report, however, of the direct measurement of the intracellular water content of erythrocytes treated with lead. We have tried to clarify the relation between the intracellular water content and the osmotic fragility of erythrocytes treated with lead in vitro

Received 27 April 1981

Accepted 16 October 1981 and have studied the effects of lead on intracellular potassium and sodium, mean corpuscular volume (MCV), plasma water, trapped water, intracellular water contents, osmotic fragility, and erythrocyte appearance.

\section{Methods}

The experiment was performed in quadruplicate in this study. Water content was measured by Kageyama's method. ${ }^{6}$ One millilitre of heparinised normal human blood was incubated for two hours at $37^{\circ} \mathrm{C}$ in an atmosphere of $5 \% \mathrm{CO}_{2}$ and $95 \%$ air with $10 \mu \mathrm{l}$ of lead acetate solution (lead concentrations in blood; $0,10,50,100,500,1000 \mathrm{nM} / \mathrm{ml}$ ) and $10 \mu \mathrm{l}$ of physiological saline containing $2 \mu \mathrm{Ci}{ }^{3} \mathrm{H}$-sucrose (Radiochemical Centre, Amsterdam) and $0.1 \mathrm{mg}$ sucrose was added; this mixture was centrifuged for 30 minutes at $3000 \mathrm{rpm}$. The haematocrit value was read, and then $50 \mu \mathrm{l}$ of the supernatant transferred with a micro syringe into a sample bottle covered with a rubber cap containing $1.95 \mathrm{ml}$ of methanol and $4.1 \%$ of $n$-buthanol as an internal standard with two glass beads to enhance the stirring efficiency. The sample bottle was shaken well and centrifuged for 10 minutes at $3000 \mathrm{rpm}$. 
The supernatant and buffy coat were completely removed from the haematocrit. The remaining packed erythrocytes were mixed well with a capillary pipette, and $50 \mu \mathrm{l}$ of the erythrocytes was injected quickly into the sample bottle with a microlitre syringe (Precision Sampling Co, USA). The sample in the bottle was shaken vigorously and centrifuged at $3000 \mathrm{rpm}$ for 10 minutes. Next, $2 \mu \mathrm{l}$ of the supernatant was taken from each bottle containing plasma or packed erythrocytes and analysed for water content by gas chromatography (Shimadzu, thermal conductivity detector Model GC-4BPTE, Japan). The water content of the plasma and packed erythrocytes was estimated by the method described above and the calibration curve for water was determined using standard samples with known water contents.

Trapped water content-The radioactivity of $50 \mu \mathrm{l}$ of the methanol supernatant was measured with a liquid scintillation spectrometer (Packerd, Model 3330 , USA), and the trapped water content was estimated as: plasma radioactivity $\div$ packed erythrocyte radioactivity $\times$ plasma water content.

Intracellular water content was calculated by subtracting the trapped water content from the packed erythrocyte water content.

Osmotic fragility of erythrocytes was determined by CPC with a coil planet centrifuge, a coiled sample tube with a range of $150-30 \mathrm{mOsmol}$, a coil incubator, and a scanning photodensitometer (Sanki Engineering, Japan). Three haemolytic points of the haemoglobin distribution pattern in the coiled tube were determined (HSP, haemolysis of the starting point: HMP, haemolysis of the maximum point: HEP, haemolysis of the end point (fig 1).

Erythrocyte count-An automatic blood cell counter (Coulter Electronics, Coulter Counter Model ZF, USA) was used.

Mean corpuscular volume was calculated by dividing the haematocrit value by the erythrocyte count.

Intracellular potassium and sodium-A 20- $\mu \mathrm{l}$ sample of blood was washed well with $0 \cdot 1 \mathrm{M} \mathrm{MgCl}_{2}$ and centrifuged. After decantation the blood was haemolysed with $4 \mathrm{ml}$ of deionised water and centrifuged. Sodium and potassium in the supernatant were determined by flame photometry (Hitachi, Model 170-50A, Japan), and these values were divided by the haematocrit value.

Erythrocyte shape was observed by scanning electron microscopy. The erythrocytes were fixed with $0 \cdot 1 \mathrm{M}$ phosphate buffer solution containing $1 \%$ glutaldehyde and with $0.5 \%$ osmic acid solution. The sample was then dehydrated with alcohol, dried at critical temperature, placed on the sample stage, ion-coated, and observed with a scanning electron microscope (JEOL, JSM-50A, Japan).

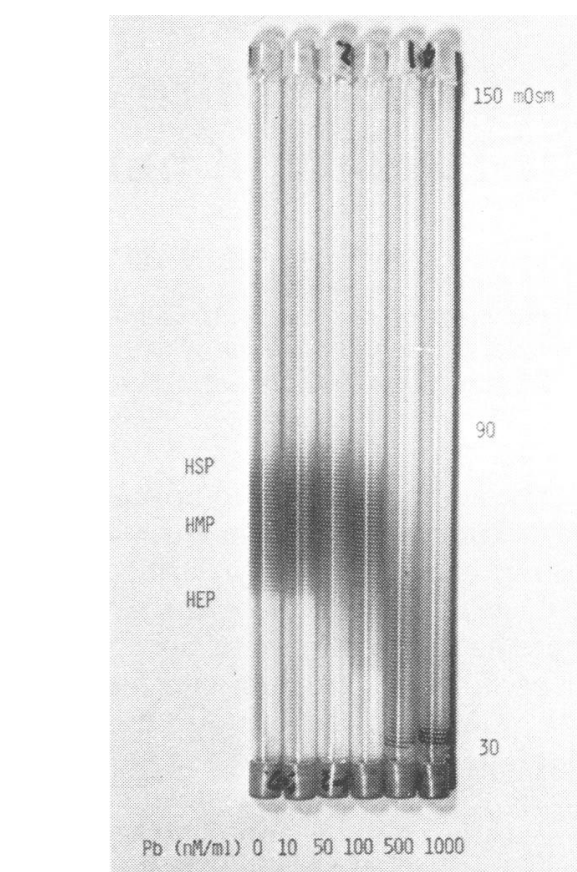

Fig 1 Haemolysis of normal human blood samples in coiled tube determined by CPC after treatment with lead in vitro at $37^{\circ} \mathrm{C}$ for two hours. Three haemolytic points of haemoglobin distribution pattern were recorded by scanning photodensitometer (haemolysis of starting point, HSP; haemolysis of maximum point, HMP; haemolysis of end point, HEP). Greatly decreased osmotic fragility in $500 \mathrm{nM} / \mathrm{ml}$ are clear.

\section{Results}

Figure 1 shows the haemolysis of normal human blood samples in the coiled tube determined by CPC after treatment with lead at $37^{\circ} \mathrm{C}$ for two hours: fig 2 shows the change of three points of haemolysis. The osmotic fragility at all three points of haemolysis decreased with $50 \mathrm{nM} / \mathrm{ml}$ of lead; it was greatly decreased with $500 \mathrm{nM} / \mathrm{ml}$ of lead.

The intracellular water content decreased considerably with $50 \mathrm{nM} / \mathrm{ml}$ of lead, then gradually decreased with increased blood lead concentration (fig 3). Plasma water content, however, gradually increased with increasing blood lead concentration (fig 4). The trapped water content increased with $50 \mathrm{nM} / \mathrm{ml}$ of lead and increased greatly with $500 \mathrm{nM} / \mathrm{ml}$ of lead (fig 5).

The changes in intracellular sodium and potassium with lead treatment are shown in fig 6 . Intracellular potassium decreased with $50 \mathrm{nM} / \mathrm{ml}$ of lead and decreased greatly with $500 \mathrm{nM} / \mathrm{ml}$ of lead. 


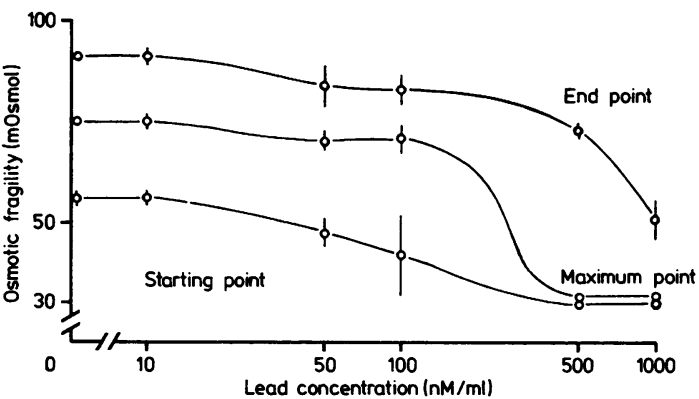

Fig 2 Change in osmotic fragility of erythrocytes. Normal human blood was incubated for two hours at $37^{\circ} \mathrm{C}$ with lead.

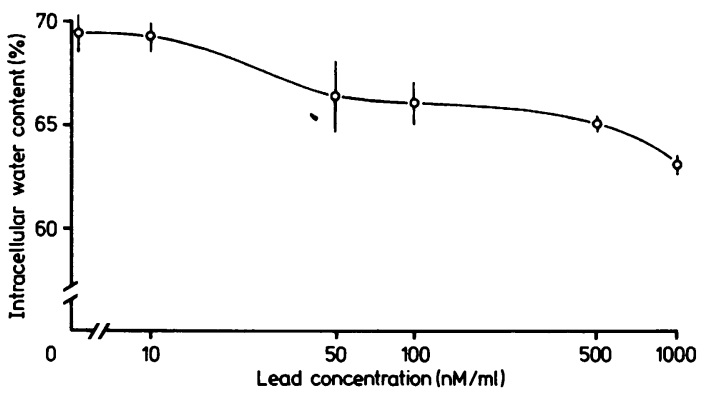

Fig 3 Change in intracellular water content. Normal human blood was incubated for two hours at $37^{\circ} \mathrm{C}$ with lead.

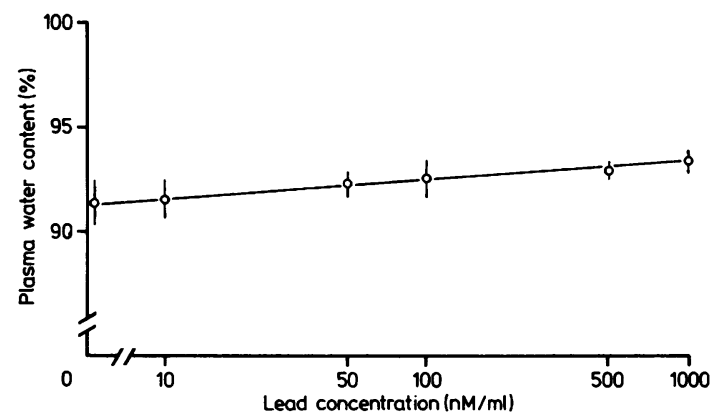

Fig 4 Change in plasma water content. Normal human blood was incubated for two hours at $37^{\circ} \mathrm{C}$ with lead.

Intracellular sodium did not change even with $1000 \mathrm{nM} / \mathrm{ml}$ of lead.

Figure 7 shows that MCV was decreased greatly with $50 \mathrm{nM} / \mathrm{ml}$ of lead, then decreased gradually with increasing blood lead concentration.

Figure 8 shows the morphological changes in erythrocytes observed with scanning electron micrographs. Erythrocytes were slightly flattened with lead compared with the controls but retained a discocyte appearance. Erythrocytes were flattened

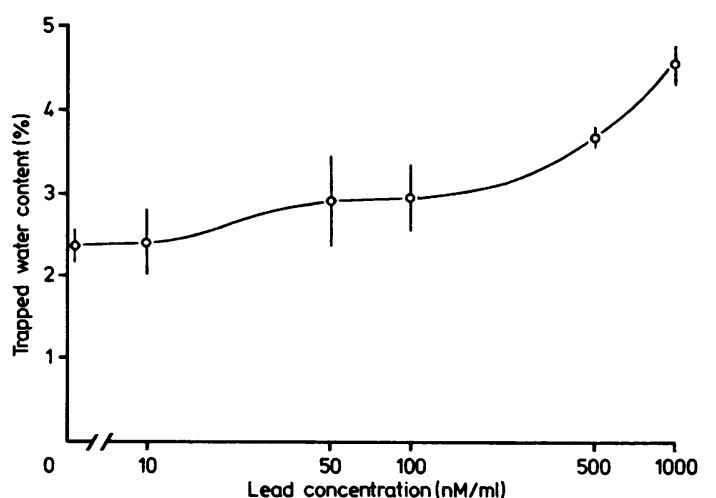

Fig 5 Change in trapped water content. Normal human biood was incubated for two hours at $37^{\circ} \mathrm{C}$ with lead.

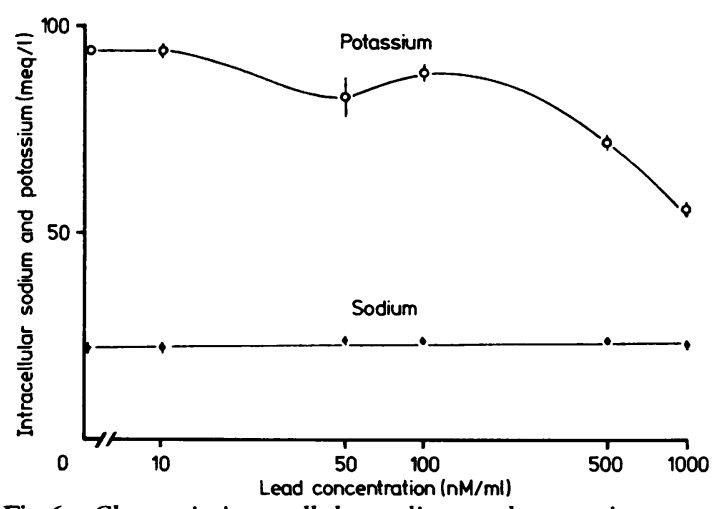

Fig 6 Change in intracellular sodium and postassium.

Normal human blood was incubated for two hours at $37^{\circ} \mathrm{C}$ with lead.

more with $1000 \mathrm{nM} / \mathrm{ml}$ of lead, and most of the erythrocytes were contracted and looked like flat discs without concaveness. The presence of echinocytes was observed.

\section{Discussion}

Changes in osmotic and mechanical fragilities of erythrocytes have been observed in vitro and in vivo, and these changes showed alterations in the morphology and permeability of the erythrocyte membrane. ${ }^{78}$ The mechanism for the decrease in osmotic fragility has not been completely clarified, however. Griggs ${ }^{5}$ proposed that lead disturbs the active transport of potassium leading to its leakage and an accompanying water loss from the erythrocytes and then a decrease in MCV. These changes indicate that more water can enter the erythrocyte before the critical spherical form and lysis occur.

Measurement of the intracellular water content 
and the water metabolism of lead-treated erythrocytes have not previously been reported. In this study we found that the addition of lead to normal human blood causes a disturbance of the water metabolism, and we also found close relationships between the change in osmotic fragility and those in intracellular water content, intracellular potassium, MCV, trapped water content, and erythrocyte shape. Therefore, our results seem to agree well with Grigg's hypothesis. ${ }^{5}$

The contracted shape of erythrocytes observed by

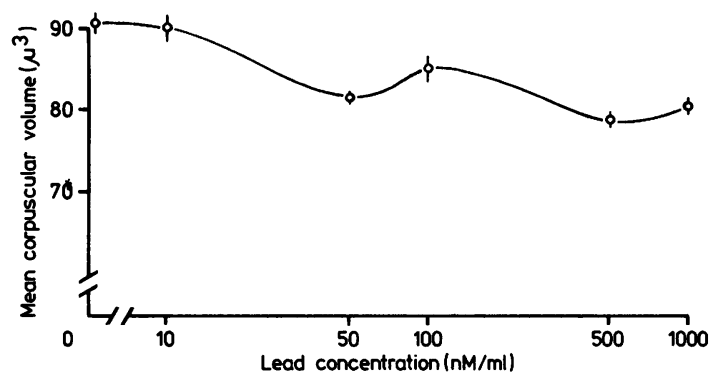

Fig 7 Change in mean corpuscular volume of erythrocytes. Normal human blood was incubated for two hours at $37^{\circ} \mathrm{C}$ with lead. scanning electron microscope indicates a decrease in erythrocyte flexibility, which leads to increases in intercellular space and trapped water content of packed erythrocytes. We assume that a pronounced increase in trapped water content with 500 and $1000 \mathrm{nM} / \mathrm{ml}$ of lead is related to the formation of echinocytes with crenation of cell membrane surface and generation of spicules caused by a pronounced decrease in intracellular potassium accompanying the water loss from the erythrocytes.

The MCV value increased a little with $1000 \mathrm{nM} /$ $\mathrm{ml}$ of lead, and was not correlated with the results of intracellular water and potassium, trapped water content, and osmotic fragility. The MCV value consists of cell volume and intracellular space. Therefore, we assume that the increased MCV with $1000 \mathrm{nM} / \mathrm{ml}$ of lead is due to the considerably increased intercellular space and trapped water content.

We thank Dr S Uni for his kind advice in operating the electron microscope.

This work was supported in part with Grant-inAid for Encouragement of Young Scientist (1981) from the Ministry of Education, Science, and Culture of Japan.
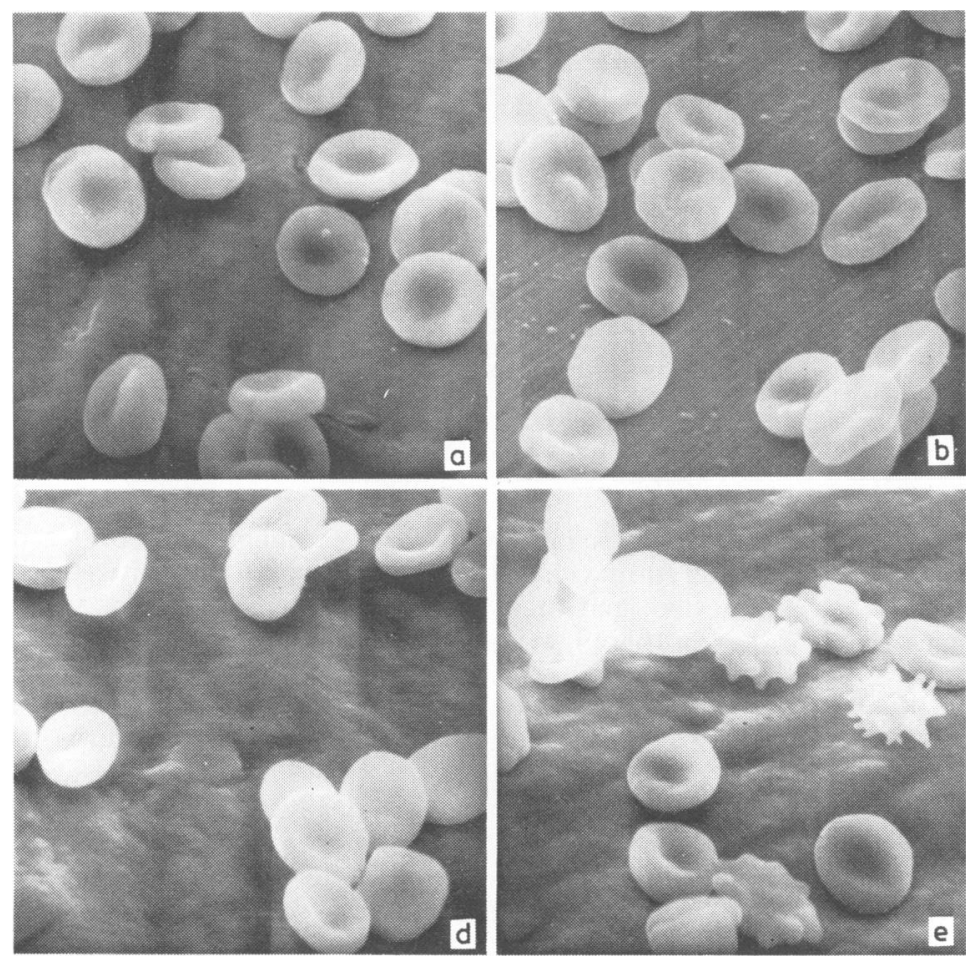

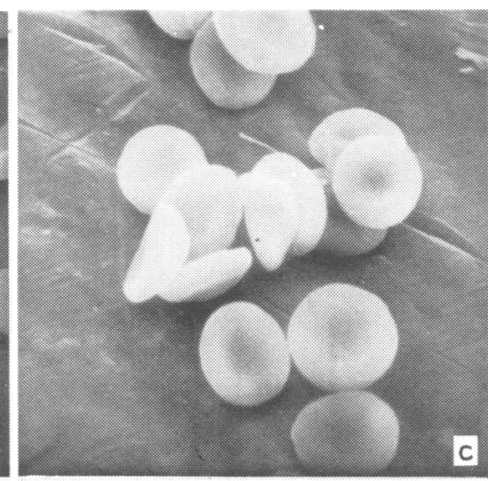

Fig 8 Scanning electron micrographs of erythrocytes. Normal human blood was incubated for two hours at $37^{\circ} \mathrm{C}$ with lead. (a) control, (b) $50 \mathrm{nM} / \mathrm{ml}$ of lead, (c) $100 \mathrm{nM} / \mathrm{ml}$ of lead,

(d) $500 \mathrm{nM} / \mathrm{ml}$ of lead,

(e) $1000 \mathrm{nM} / \mathrm{ml}$ of lead. 


\section{References}

' Horiguchi S, Teramato K, Nakano H, Shinagawa K, Endo G, Kiyota I. Osmotic fragility test of red blood cells of lead workers by coil planet centrifuge. Osaki City Med J 1974;20:51-3.

${ }^{2}$ Karai I, Fukumoto K, Horiguchi S. Studies on osmotic fragility of red blood cells determined with a coil planet centrifuge for workers occupationally exposed to lead. Int Arch Occup Environ Health 1981;48:273-81.

${ }^{3}$ Ito Y, Weinstein MA, Aoki I, Harada R, Kimura E, Nunogaki K. The coil planet centrifuge. Nature 1966;212:985-7.

${ }^{4}$ Karai I, Fukumoto K, Horiguchi S. The effects of heavy metal ions on osmotic resistance of human red blood cells. Osaka City Med J 1979;25:153-7.

${ }^{5}$ Griggs RC. Lead poisoning: hematologic aspects. Prog Hematol $1964 ; 4: 117-37$.

- Kageyama K. Effect of incubation on red cell shape and water content as measured by gas-liquid chromatography. Nouv Rev Fr Hématol 1979;21161-9.

' Joyce CRB, Moore H, Weatherall $M$. The effect of lead, mercury and gold on the potassium turnover of rabbit blood cells. $\mathrm{Br}$ J Pharmacol 1954;9:463-70.

Vincent PC, Blackburn CRB. Effect of heavy metal ions on the human erythrocyte. 1 Comparison of the action of several heavy metals. Aust J Exp Biol Med Sci 1958;36:471-80.

\section{The May 1982 issue}

\section{THE MAY 1982 ISSUE CONTAINS THE FOLLOWING PAPERS}

Health implications of exposure to radiofrequency/microwave energies SM MICHAELSON

Coalworkers' simple pneumoconiosis and exposure to dust at 10 British coalmines JF HURLEY, J BURNS, LIZ COPLAND, J DODGSON, AND M JACOBSEN

Tetrachlorodibenzodioxin: a survey of subjects ten years after exposure GMAY

Elemental mercury exposure: peripheral neurotoxicity S P LEVINE, G D CAVENDER, G D LANGOLF, AND J W ALBERS

Actual hazard of methyl bromide fumigation in soil disinfection R VAN DEN OEVER, D ROOSELS, AND D LAHAYE

Epilepsy in the British Steel Corporation: an evaluation of sickness, accident, and work records

A K DASGUPTA, M SAUNDERS, AND D J DICK

Absences attributed to respiratory diseases in welders R F FAWER, A WARD GARDNER, AND D OAKES Mechanism of increased osmotic resistance of red cells in workers exposed to lead I KARAI, K FUKUMOTO, AND S HORIGUCHI

Assessment of the body burden of chelatable lead: a model and its application to lead workers S ARAKI AND K USHIO

Value of the simultaneous determination of $\mathrm{PCO}_{2}$ in monitoring exposure to 1,1,1-trichloroethane by breath analysis M GUILLEMIN AND E GUBERAN

Angiographic study of digital arteries in workers exposed to vinyl chloride P FALAPPA, N MAGNAVITA, A BERGAMASCHI, AND N COLAVITA
Urinary excretion of hydroxyproline in workers occupationally exposed to vibration T KASAMATSU, K MIYASHITA, S SHIOMI, AND H IWATA

Adrenocortical suppression in workers employed in manufacturing synthetic glucocorticosteroids: solutions to a problem $R$ W NEWTON, MARGARET C K BROWNING, P C NICHOLSON, AND D A E MOWAT

Lack of allergic reactions in workers exposed to Pruteen (bacterial single-cell protein) R W MAYES

TLC separation of hippuric, mandelic, and phenylglyoxylic acids from urine after mixed exposure to toluene and styrene GRAŻYNA BIENIEK, EWA PALYS, AND T WILCZOK

Analysis of fibres in human lung tissue B GYLSETH, R H BAUNAN, AND L OVERAAE

Cancer morbidity among polishers B JÄRVHOLM, G THIRINGER, AND O AXELSON

Notes and miscellanea

Interaction between drugs and solvents as a cause of fatty change in the liver? C EDLING

Hanford radiation study $R$ H MOLE

Book reviews

Information section

Corrections:

Healthy worker effect in the total Finnish population (May 1980, p. 180-184)

A study of the mortality of Cornish tin miners (November 1981, p. 378-380)

Relationship between type of simple coalworkers' pneumoconiosis and lung function. (November 1981, p. 313-320)

Copies are still available and may be obtained from the PUBLISHING MANAGER, BRITISH MEDICAL ASSOCIATION, TAVISTOCK SQUARE, LONDON WC1H 9JR, price $£ 4.25$ (USA \$9.20), including postage 